\title{
What Predisposing Factors Affect Nurses' Islamic Behavior?
}

\author{
Siti Sangadatul Wahidah Alqudsiyah ${ }^{1}$, Puguh Widiyanto ${ }^{1 *}$, Heni Setyowati Esti \\ Rahayu $^{1}$
}

${ }^{1}$ Faculty of Health Sciences, Universitas Muhammadiyah Magelang, Indonesia

${ }^{*}$ Corresponding author. Email: puguh.widiyanto@ummgl.ac.id

\begin{abstract}
The quality of hospital services continues experiencing competition that requires new innovations to nurses. Nurses as providers of nursing care are not only required to achieve physical healing of patients, but also psychological, spiritual, and social aspects, by applying Islamic behavior in every action. In Islamic behavior is influenced by several factors including knowledge of Islamic behavior and attitudes towards Islamic behavior. This research was conducted to determine the predisposing factors (knowledge and attitudes) that influence the Islamic behavior of nurses. The research was an analytical survey with a cross-sectional study approach (cross section). The study was conducted in February-August 2019. The population in this study were all inpatient nurses in Aisyiyah Muntilan Hospital, Magelang Regency, with 57 people using purposive sampling, a sample of 49 nurses who were in accordance with the inclusion criteria. The data obtained from the questionnaire measuring instrument with the checklist method. Bivariate analysis using the Spearman test Rank $\alpha=0.05$ significance level $95 \%$. The results of the correlation analysis of predisposing factors produced data on the relationship between knowledge about Islamic behavior with Islamic behavior, it was found that the $\mathrm{p}$ value $=0.001$ and $\mathrm{r}=0.537$. The relationship between attitudes towards Islamic behavior with Islamic behavior obtained probability $p$ value $=0.092$ and $r=0.246$. There was a relationship between knowledge about Islamic behavior with Islamic behavior of nurses. There was no relationship between attitudes towards Islamic behavior and Islamic behavior of nurses. So, it can be concluded that of the two predisposing factors, which influence nurses' Islamic behavior is the knowledge factor about Islamic behavior. From the results of this study, it was necessary to make policies to improve and maintain nurses' knowledge and attitudes so that the Islamic behavior of nurses can increase in the provision of nursing care.
\end{abstract}

Keywords: predisposing factors, nurses, Islamic behavior

\section{INTRODUCTION}

The formulation of a hospital's vision is an important process in the hospital's strategic actions. Various interpretations that are raised intelligently will motivate leaders to think about the goals of the establishment of the hospital and the state of the hospital that is aspired to in the future. The hospital's vision is essential for a hospital to ensure long-term sustainability and success. In fact, Pearce \& Robinson states that vision is a statement that illustrates the strategic intent of a hospital that is designed to focus the hospital's energy and resources to achieve the aspirated future [1].

Hax \& Majluf explain that a vision of success will be communicated transparently, used as a reference in the growth and development of hospital performance, as well as creating a conducive relationship between stakeholders (human resources, consumers, and other related parties) [2]. The vision of the hospital has a major influence on changes in the global situation and competition between hospitals is unavoidable. A clear management strategy is needed to make the vision the direction of hospital development in
Indonesia. This management strategy will encourage hospitals to continue to improve the quality of their services. Quality of service is an approach in carrying out hospital management that continues to strive to maximize the state of the hospital in competing with other hospitals. Hospital competition is carried out through various continuous improvements from the stakeholders involved as well as hospital facilities and infrastructure. A management strategy that is focused on ensuring satisfaction for the community, teamwork and empowering health workers is needed [3].

Community satisfaction is the response of people's pleasure or disappointment to the suitability of the interests or expectations of the community before receiving health services after receiving health services [4]. Community satisfaction is one of the goals in improving the quality of health services. Society now considers the value of good and bad and halal based on their beliefs.

Muslim population in Indonesia reaches $91.94 \%$, a strong reason to create an Islamic-based business including health services and hospitals. Until now, Islamic-based hospitals that provide Islamic services have not been sufficient enough with the demands needed by the community [5]. 
Aisyiah Muntilan Hospital has a vision "To be the first choice of the people of Magelang Regency and its surrounding areas that provide excellent service, namely: superior, Islamic, and progressive." Superior means professional, pass plenary accreditation, human resources according to the standard of facilities and infrastructure according to hospital class standards, excellent service. Islamic means employees with Islamic life principles (PHIWM), Islamic services, Islamic governance. Progress means sustainable growth: assets, quality of human resources, facilities and service infrastructure.

Aisyiah Muntilan Hospital as a hospital with Islamic nuance is expected to be able to create Islamic activities by applying Islamic morals in each of its services. So that actions to improve the quality of services oriented to improving the quality of employee HR to be principled in providing Islamic behavior behave, especially for nurses because nurses will be in constant contact with patients in providing nursing care.

Nursing care is the main thing in health services in hospitals that maintain patient health for 24 hours continuously without stopping. In its treatment, a patient needs a series of treatments that can provide healing or overcome the problems they are experiencing. Problems that are overcome are not only healing from physical aspects, but also psychological, spiritual, and social aspects, namely by behaving in an Islamic manner by linking caring attitude of nurses performed in their nursing care [6]. Nurses are health workers who have the most number in hospitals and play an important role in providing professional and quality services. Professional nurses are filled with knowledge, skills, attitudes, and interpersonal practices that reflect behaviors that contain Islamic moral values.

Behavior is a response that arises from the nurse due to external stimuli. Lawrence W. Green, explain that there are 3 factors for the formation of Islamic behavior, namely predisposing factors (knowledge, attitudes, beliefs and beliefs), reinforcing factors (physical environment, infrastructure, and worship facilities provided by health services), and driving factors (health service leadership attitudes or hospitals) [7].

Predisposing factors or predisposing factors are factors originating from the nurses themselves who are driving a nurse to make changes in behavior. The driving factors include knowledge, attitudes, beliefs, beliefs, values, and norms [8]. Predisposing factors can come from experiences that are remembered by individuals, both experiences from others or the experiences of nurses themselves. Predisposing factors are factors that must be fulfilled by nurses and hospitals in order to become an advantage and focus in achieving quality of service to the community. According to Setyaningsih results that there is a significant relationship between knowledge with the practice of nursing care, while the attitude of nursing care practices there is no significant relationship [9].
Research according to Magdalena results that religious moral behavior is more important is the educational background, then the status of student organizations [10]. The school is a place and vehicle in passing down or transferring knowledge and values adopted in accordance with the orientation of each school. Schools are also a place to get to know organizations. While the gender values were found to influence but did not make a difference in religious moral behavior.

Research on Islamic hospital services according to Sunawi yields the following conclusions: (1) Health services in Surakarta Islamic Hospital apply four characters to their Islamic services, including Rabbaniyah, Akhlaqiyah, al Waqi'iyah and Insaniyah. In addition, four basic concepts for Islamic services also apply including al Yusru, al Tadarruj, al Ihsan and Mardhatillah. (2) Islamic Maintenance of Surakarta Islamic Hospital is implemented in the implementation of Islamic values (Islamization) of each service, for example: patient services, medical expense services, maintenance of patient administration data, maintenance of the hospital's physical environment, and other non-medical services [11].

The behavioral aspects of Islamic officer nurses must be the focus of Islamic hospital management strategies. Nurses' Islamic behavioral management strategies that will realize the achievement of the Islamic hospital's vision. Islamic nurse behavior is a behavior possessed by a nurse towards patients and the surrounding environment that contains intrinsic moral values in providing nursing care [12]. The nurse's Islamic behavior arises with reason to meet the spiritual needs of patients who are rahmatan lil alamin or compassion for all beings regardless of race, ethnicity, nationality, language, and religion.

\section{METHOD}

This research uses a quantitative method using a cross sectional study approach. The population of this study is nurses at Aisyiyah Muntilan Hospital. The samples in this study were 49 nurse respondents and 98 patient respondents with purposive sampling, namely from the Mina room of 13 nurses, 6 nurses 'infants' rooms, 18 nurses 'Shofa rooms, 9 nurses' Roudhoh rooms and 9 maternity rooms 3 nurses. The study was conducted in May to June 2019 with research tools using a nurse characteristic questionnaire, a nurse's knowledge and attitude questionnaire, and a nurse's Islamic behavior questionnaire. Data were analyzed using the Spearman rho test and Logistic Regression.

\section{RESULTS AND DISCUSSION}

The results of the study can be seen in the following table: 
Table 1 Relationship between attitudes toward Islamic behavior with nurse Islamic behavior

\begin{tabular}{|c|c|c|c|c|c|c|c|c|c|}
\hline \multirow{3}{*}{ Attitudes towards Islamic Behavior } & \multicolumn{6}{|c|}{ Islamic Behavior } & \multirow{3}{*}{ Total } & \multirow{3}{*}{$p$} & \multirow{3}{*}{$\mathbf{R}$} \\
\hline & \multicolumn{2}{|c|}{ Good } & \multicolumn{2}{|c|}{ Enough } & \multicolumn{2}{|c|}{ Lack } & & & \\
\hline & $\mathbf{N}$ & $\%$ & $\mathbf{N}$ & $\%$ & $\mathbf{N}$ & $\%$ & & & \\
\hline Good & 32 & 65.3 & 5 & 10.2 & 0 & 0 & $75.5 \%$ & & \\
\hline Enough & 8 & 16.3 & 4 & 8.2 & 0 & 0 & $24.5 \%$ & 0.092 & 0.246 \\
\hline Lacking & 0 & 0 & 0 & 0 & 0 & 0 & 0 & & \\
\hline Total & 40 & 81.6 & 9 & 18.4 & 0 & 0 & $100 \%$ & & \\
\hline
\end{tabular}

Table 2 Relationship between knowledge of Islamic behavior and attitudes towards Islamic behavior with nurse Islamic behavior

\begin{tabular}{|lccc|}
\hline \multicolumn{1}{|c|}{ Variable } & OR (exp. B) & 95\% CI (exp. B) & $p$ \\
\hline Knowledge of Islamic Behavior & 0,502 & 1.652 & 0,026 \\
Attitudes towards Islamic Behavior & 0,166 & 1.181 & 0,146 \\
\hline
\end{tabular}

The results showed there was a positive relationship between nurses 'knowledge and Islamic nurses' behavior with the Spearman rho test obtained $p$ value $=0.001$ ( $p$ value $<0.05$ ). Knowledge has a significant effect on the delivery of nurses' spiritual care [13]. Nurses to be able to perform Islamic behavior to patients require extensive insight. Knowledge plays an important role for nurses to be able to implement Islamic behavior in providing nursing care.

Nurse knowledge is one of the predisposing factors of a behavior. The analysis showed that most nurses in the inpatient room who had good knowledge and good behavior were $40(81.6 \%)$. Knowledge of nurses can continue to increase if the hospital can continue to improve the ability of nurses by holding a variety of training for all employees, especially nurses inpatient care in aspects of implementing Islamic behavior in the Aisyiyah Muntilan Hospital, Magelang Regency.

The results showed as many as $32(65.3 \%)$ had good attitudes and good Islamic behavior. Five $(10.2 \%)$ had good attitude and behaved sufficiently. A total of $8(16.3 \%)$ had sufficient attitudes and good behavior. As many as 4 (8.2\%) have enough attitude and enough behavior. Statistical test results using the Spearman test obtained $p$ value $=0.092>$ $0.05(\alpha=0.50)$ which means there is no relationship between attitudes towards Islamic behavior with Islamic behavior of nurses.

The absence of a relationship between attitudes towards Islamic behavior with Islamic behavior occurs when there is no belief in a nurse's attitude in implementing Islamic behavior and tends to think negatively or care less about the spiritual needs of the patient, so the application of Islamic behavior becomes unfavorable, according to the theory which states that attitude of a behavior is influenced by the belief that the behavior will give a desired or undesirable outcome [14]. Attitude as a pattern of behavior, tendency or anticipatory readiness, predisposition to adjust to social situations, or simply, attitude is a response to social stimuli that have been conditioned. As a nurse, the main professional attitude is how to show empathy to the client. This attitude is actually very influential on the healing of a client.

The consistency-dependent postulate states that the relationship between attitude and behavior is largely determined by certain situational factors. Norms, roles, group membership, and culture in a hospital are conditions of dependency that can change the relationship between attitude and behavior. Allen, Guy \& Edgley explain that therefore, the extent to which behavior predictions can be based on attitudes will differ from time to time and from situation to situation.

The results showed the results of the regression test between knowledge and attitude with the Islamic behavior of nurses. Based on the logistic regression test results obtained $p$ value for between knowledge with Islamic behavior of nurses $=$ 0.026 ( $\mathrm{p}$ value $<0.05$ ) with OR of 0,502 . While between attitudes with Islamic behavior of nurses obtained $p$ value $=$ 0.146 ( $\mathrm{p}$ value $>0.05$ ) with OR 0.166 . With the logistic regression test it can be seen that the formation of Islamic behavior is influenced by knowledge of Islamic behavior by $50.2 \%$.

\section{CONCLUSION}

Based on the results of research on Predisposing Factors that Influence the Islamic Behavior of Nurses at Aisyiyah Muntilan Hospital, Magelang Regency, it can be concluded as there is a significant influence between knowledge of Islamic behavior with Islamic behavior of nurses in the inpatient room of Aisyiyah Muntilan Hospital in Magelang District with a strong positive relationship pattern which means the better the knowledge possessed will perform good Islamic behavior. There is no influence between the attitude of Islamic behavior towards the Islamic behavior of nurses in the inpatient room of Aisyiyah Muntilan Hospital, Magelang Regency. Factors that influence the application of Islamic behavior and become a reference in improving the application of Islamic behavior in the provision of nursing care, including education, training, and rules related to the application of Islamic behavior. For this reason, the role of management, especially the head of nursing, is very important in building nurse resources.

\section{REFERENCES}

[1] Pearce, J. A., \& Robinson, R. B. Manajemen Strategis (Formulasi, Implementasi, dan Pengendalian) (12th ed.). Yogyakarta: Salemba Empat. (2013). 
Penerapan Standar Asuhan Keperawatan di RSUD Kabupaten Sragen. Skripsi, 303085. Retrieved from http://eprints.undip.ac.id/20596/1/2472.pdf. (2005).

[11] Sunawi. Konsep Pelayanan Kesehatan Islami di Rumah Sakit (Tinjauan Aplikasi di Rumah Sakit Islam Surakarta). Digital Times, Unknown (Unknown), No Pages. Retrieved from http://eprints.ums.ac.id/20804/18/Naskah_Publikasi.pdf . (2012).

[10] Magdalena. Analisis Faktor-Faktor yang Mempengaruhi Perilaku Moral Keagamaan Mahasiswa. Thesis Program Pasca Sarjana Strata Tiga (S3) IAINU SU Medan, 91, 399-404. Retrieved from http://jurnal.iainpadangsidimpuan.ac.id/index.php/TZ/article/download/ 100/89. (2014).

[12] Miswanto, A. Seri Studi Islam : Agama, Keyakinan, dan Etika. (Z. Arofi, Ed.). Magelang: Pusat Pembinaan dan Pengembangan Studi Islam Universitas Muhammadiyah Magelang (P3SI UMM). (2012).

[13] Fitriyah, N. A. Analisa Faktor-Faktor yang Mempengaruhi Perawat Dalam Pemenuhan Kebutuhan Spiritual pada Pasien Rawat Inap di Rumah Sakit Anton Soedjarwo Pontianak. Retrieved from http://jurnal.untan.ac.id/index.php/jmkeperawatnFK/arti cle/viewFile/15994/13932. (2016).

[14] Azwar, S. Sikap Manusia Teori dan Pengukurannya. (D. K. K., Ed.) (2nd ed.). Yogyakarta: Pustaka Pelajar. (2016).
[9] Setyaningsih, H. D. Faktor-Faktor yang
Berhubungan dengan Perilaku Perawat terhadap

[9] Setyaningsih, H. D. Faktor-Faktor yang
Berhubungan dengan Perilaku Perawat terhadap
[8] Nurdina. Analysis of Lawrence Green Theory Concerning Pregnancy Sexuality Behavior to Sexual Behavior Change in Primigravida in Kediri. Journal of Applied Environmental and Biological Sciences, 8(1), 23-28. Retrieved from www.textroad.com. (2018). 